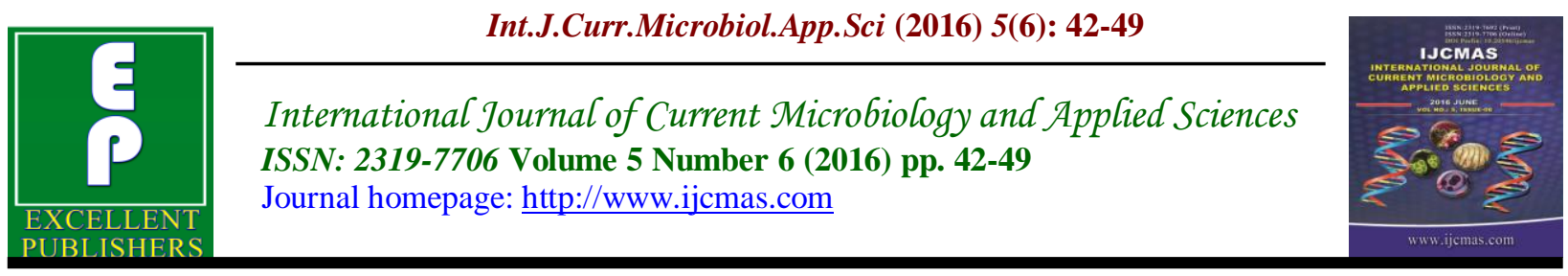

Original Research Article

http://dx.doi.org/10.20546/ijcmas.2016.506.005

\title{
Air Quality Monitoring of Operation Theaters in Government Medical College and Hospital, Aurangabad, India
}

\author{
M.M. Kasdekar, M.M. Duthade*, A.S. Damle, M.N. Khapurkuntikar, \\ J.A. Iravane, J.B. Bhakre and A.A. Gaikwad \\ Department of Microbiology, Government Medical College, Aurangabad, India \\ *Corresponding author
}

\begin{abstract}
A B S T R A C T
Keywords

Air quality monitoring, Settle plates, Operation theatres (OT).

\section{Article Info}

Accepted:

07 May 2016 Available Online: 10 June 2016

Air quality of any place reflects its hygienic condition, especially in health care centres like hospitals there are higher chances of infectious microorganisms to be present suspended in the environment, air quality monitoring hence plays important role so as to keep check on the environment and take useful measures to improve it. Air quality monitoring of operation theatres is more important as there are higher chances of microorganisms suspended in air to get settled in operation site later resulting into post-operative surgical site infections and consequently increasing morbidity and mortality. This study was aimed to monitor Quality of air in the form of bacterial load in operation theatres by Settle plate method (passive air sampling), to identify the presence of fungi and to see the rate of infection in postoperative patients in respective wards of hospital. 100 settle plates were studied from 6 different Operation Theatres (OT) from Hospital in a period of one year January 2015 to December 2015. Out of 100 settle plates 28 plates were positive showing discrete macroscopic bacterial or fungal colonies. Among 28 positives OT 1 and OT 4 both shows 9 and 8 settle plates of maximum positives respectively.OT3 shows 5, OT 2 shows 4 and CVTS and CVTS Cath lab shows positive for one settle plates each. Organisms isolated were Staphylococcus aureus (57\%), Pseudomonas spp (7\%), other gram negative organisms and fungal species of Aspergillus niger (7\%). Patients who had undergone surgeries in OTs with settle plate positive were followed up for any post-operative surgical site infections. Harbouring of potential pathogens in OTs of hospital can pose a great risk to patients operated in hospital.
\end{abstract}

\section{Introduction}

Microbial contamination of air/surfaces /articles in OTs is a major cause of surgical site and nosocomial infections (Bhalla et al., 2007). Air bio-load present in the form of aerosols may contain bacteria, viruses, yeasts, moulds and fungal spores.
These may be present in patients own endogenous flora, health care persons and from environment sources (Sehulster et al., 2003) Environmental monitoring means the microbiological testing of air, surface and equipment in order to detect changing trends of microbial counts and micro-flora 
monitoring the capability of the air filters used in the OT's and also helps in assessing quality and making timely changes in measures that need to be adopted in order to maintain air quality in these areas (Javed et al., 2008).

The air in operating theatres environment is said to have a role in the causation of postoperative infections. Post-operative infection constitutes a third of all infections. Infection prevention measures that needs to be practiced, to avoid such situation rest not only on operating personnel but would also involve the entire infection control team and role of clinical microbiologist in terms of monitoring air quality. It is in fact estimated that a 13-fold reduction in airborne bacteria in operating rooms would reduce wound contamination by around $50 \%$ (Whyte et al., 1992). Air sampling therefore plays important role in monitoring of hygienic conditions in operation theatres.

Air samples can be collected in two ways:

\section{1) Active air samplers}

2) Passive air sampling (the settle plates).

In this study settle plate method was used for air quality monitoring of operation theatres. Settle plates when exposed to the atmosphere, collect particles settling by gravity. This method is simple frequently used, sometimes in preference to other aerobiological samplers. Settle plates are passive method which represents large particles sampled during exposure period because of the faster sedimentation rate.

Use of settle plate can provide a hint whether the environment is more or least contaminated with airborne microorganisms (Srikant et al., 2008).
The main and objectives of this study includes, to monitor Quality of air in the form of bacterial load in operation theatres by Settle plate method. And to identify the presence of fungi. Also to identify the rate of infection in postoperative patients in respective wards of hospital.

\section{Materials and Methods}

The Study was conducted in department of Microbiology, Government Medical College and Hospital, Aurangabad. The study period was from January 2015 to December 2015. Settle plates were collected from 6 different operational theatres (OTs) in the hospitals. Total numbers of 100 Settle plates were studied in a year. Settle plates were collected once in a month from each OT.

The evaluation of bacterial contamination in an operating theatre was performed by using settle plate method. The sterile Blood agar plates were transported to operation theatres in sealed plastic bags. The plates were labelled with sample number, site within the operation theatre, time and date of sample collection and control plates were kept to monitor any prior contamination of plates. During air sampling sterile gloves, mouth mask and protective gown were worn to prevent self-contamination of the blood agar plate. The index of microbial air contamination was based on the count of the microbial fallout on to petridishes left open to the air according to the $1 / 1 / 1$ scheme (for 1 hour, 1 meter above the floor, at least $1 \mathrm{~m}$ away from walls or any obstacle). After this exposure, the plates were covered with their lids and taken to Microbiology laboratory in sealed plastic bags and incubated in incubator at $37^{\circ} \mathrm{C}$ for 24 hours The culture plates that showed discrete macroscopic colonies were counted using digital colony counter. The colonies were assessed for the growth of potential pathogenic bacteria 
initially by colony characteristics, haemolysis pattern and microscopic examination of Gram stained smears. Final identification was done following standard bacteriological techniques. The concentration of airborne bacteria was expressed as colony forming units per cubic meter $\left(\mathrm{cfu} / \mathrm{m}^{3}\right.$. Settle plate showing fungus was also noted. LCB mount of fungi was done to identify it. Patients who had undergone surgeries at the time of air quality monitoring, were followed up for any postoperative surgical site wound infection.

\section{Reporting of Settle Plates}

1. Single CFU of Staphylococcus spp., Pseudomonas spp., any fungi.

2. $>50 \mathrm{CFU}$ of Gram negative bacteria other than Pseudomonas spp.

\section{Formula for Conversion of Colony Count} (on settle plate) to Counts / $\mathrm{m}^{3}$

$$
\mathrm{CFU} / \mathrm{m}^{3}=\frac{\mathrm{a} \times 1000}{\mathrm{p} \times \mathrm{t} \times 0.2}
$$

$\mathrm{a}=$ The number of colonies on Settle plate.

$p=$ The surface measurement of plate used.

$t=$ Time of exposure of settle plate.

\section{Results and Discussion}

In Table 1: Out of 100 settle plates observed from OTs 28 plates were showing growth of organisms and were positive and the report was given as not satisfactory. Among 28 positives OT 1 and OT 4 both shows 9 and 8 settle plates of maximum positives respectively.OT3 shows 5, OT 2 shows 4 and CVTS and CVTS Cath lab shows positive for one settle plates each.

Table no. 2: Among 28 positive samples from different OTs, OT 1 had maximum positivity that is $32.15 \%$, OT 2 had $14.29 \%$ of positive samples, OT 3 had $17.85 \%$ of positive samples, OT 4 had $28.57 \%$ of positive samples, CVTS OT and CVTS cath lab had $3.57 \%$ of positive samples each.

Table no. 3: Out of 28 settle plates positives maximum 16 (57\%) plates showed colonies of Staphylococcus aureus, 2 (7\%) plates showed fungal colonies of Aspergillus niger and $2(7 \%)$ plates showed colonies of Pseudomonas spp. 8 (29\%) plates showed significant colony counts of other bacteria.

Corrective Actions were advised to take in OT showing non significant

1. Cleaning of OT with liquid soap and water after removal of dust on all surfaces.

2. Cleaning OT tables, lamps, trolleys with proper disinfectant.

3. Fumigation of OT.

4. Restrict entry of personnel in OT and wear masks and caps while in OT.

The microbiological quality of air in operation theatre has a huge bearing on the outcome of any surgical procedure. The microbiological quality of air can indeed be considered as a reflection of the hygienic condition of operating room.

In our study out of 100 settle plates studied 28 plates were found to be positives. Among the total operational theatre studied OT1 and OT 4 in our hospital were showing positives for gram positive cocci, gram negative bacteria and fungi. Analysis of the settle plates (passive) method from various operational theatres for microbial load has shown $57 \%$ of Gram positive cocci to be predominant. Similar isolation was shown in study done by Rajni Sabharwal et al., 2015. Gram negative bacteria were detected in $7 \%$ 
and found to be Pseudomonas species. Fungi were also isolated in $7 \%$ of which was identified as Aspergillus niger. Grampositive bacteria isolated from the plates were predominantly of cocci in nature and were pathogenic and found to be Staphylococcus aureus.

Table.1 Shows Total Numbers of Settle Plates Showing Positives in Different OTs.

\begin{tabular}{|c|c|c|c|c|}
\hline Sr. No & $\begin{array}{l}\text { OT number } \\
\text { in hospital }\end{array}$ & $\begin{array}{l}\text { Number of } \\
\text { settle plates } \\
\text { observed }\end{array}$ & $\begin{array}{l}\text { Settle Plates showing } \\
\text { growth (Positive) }\end{array}$ & $\begin{array}{l}\text { Settle plate showing } \\
\text { no growth } \\
\text { (Negative) }\end{array}$ \\
\hline 1. & OT 1(all blocks) & 31 & 9 & 22 \\
\hline 2. & OT2 (all blocks) & 20 & 4 & 16 \\
\hline 3. & OT3 (all blocks) & 18 & 5 & 13 \\
\hline 4. & 0T 4 (all blocks) & 22 & 8 & 14 \\
\hline 5. & CVTS OT & 4 & 1 & 3 \\
\hline \multirow[t]{2}{*}{6.} & CVTS Cath lab & 5 & 1 & 3 \\
\hline & TOTAL & 100 & 28 & 72 \\
\hline
\end{tabular}

Table.2 Shows Percentage Distribution of all Positive Samples from different OTs.

\begin{tabular}{|l|l|l|}
\hline OT & Positive samples & Percentage of Positivity (\%) \\
\hline OT 1 & 9 & 32.15 \\
\hline OT 2 & 4 & 14.29 \\
\hline OT 3 & 5 & 17.85 \\
\hline OT 4 & 8 & 28.57 \\
\hline CVTS OT & 1 & 3.57 \\
\hline CVTS Cath lab & 1 & 3.57 \\
\hline TOTAL & $\mathbf{2 8}$ & $\mathbf{1 0 0}$ \\
\hline
\end{tabular}

Table.3 Distribution of Organism isolated from positive samples.

\begin{tabular}{|l|l|l|}
\hline Organism Isolated & Number of plates & Percentage (\%) \\
\hline Staphylococcus aureus & 16 & 57 \\
\hline Pseudomonas spp. & 2 & 7 \\
\hline Aspergillus niger & 2 & 7 \\
\hline Other bacteria & 8 & 29 \\
\hline Total & 28 & 100 \\
\hline
\end{tabular}


Fig.1 Shows Out of 100 Settle Plates Studied 72\% Samples were Satisfactory and 28\% Samples Were Unsatisfactory.

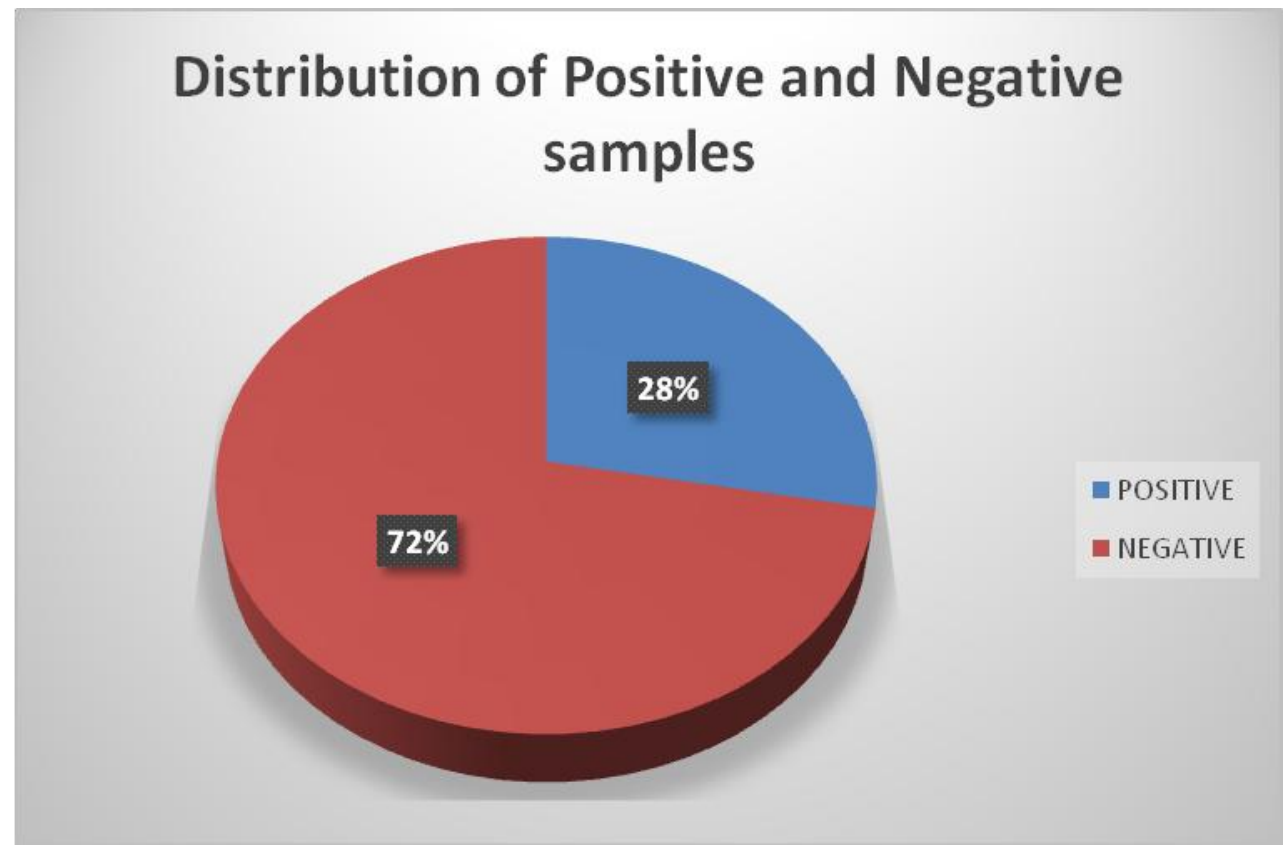

Fig.2 Shows Distribution of Unsatisfactory Samples, 1 Showed 29\% Unsatisfactory samples, OT 2 showed 14\% unsatisfactory samples, OT3 had 18\% unsatisfactory samples while OT 4, CVTS OT and CVTS Cath lab had 29\%, 3\% and 7\% unsatisfactory samples respectively.

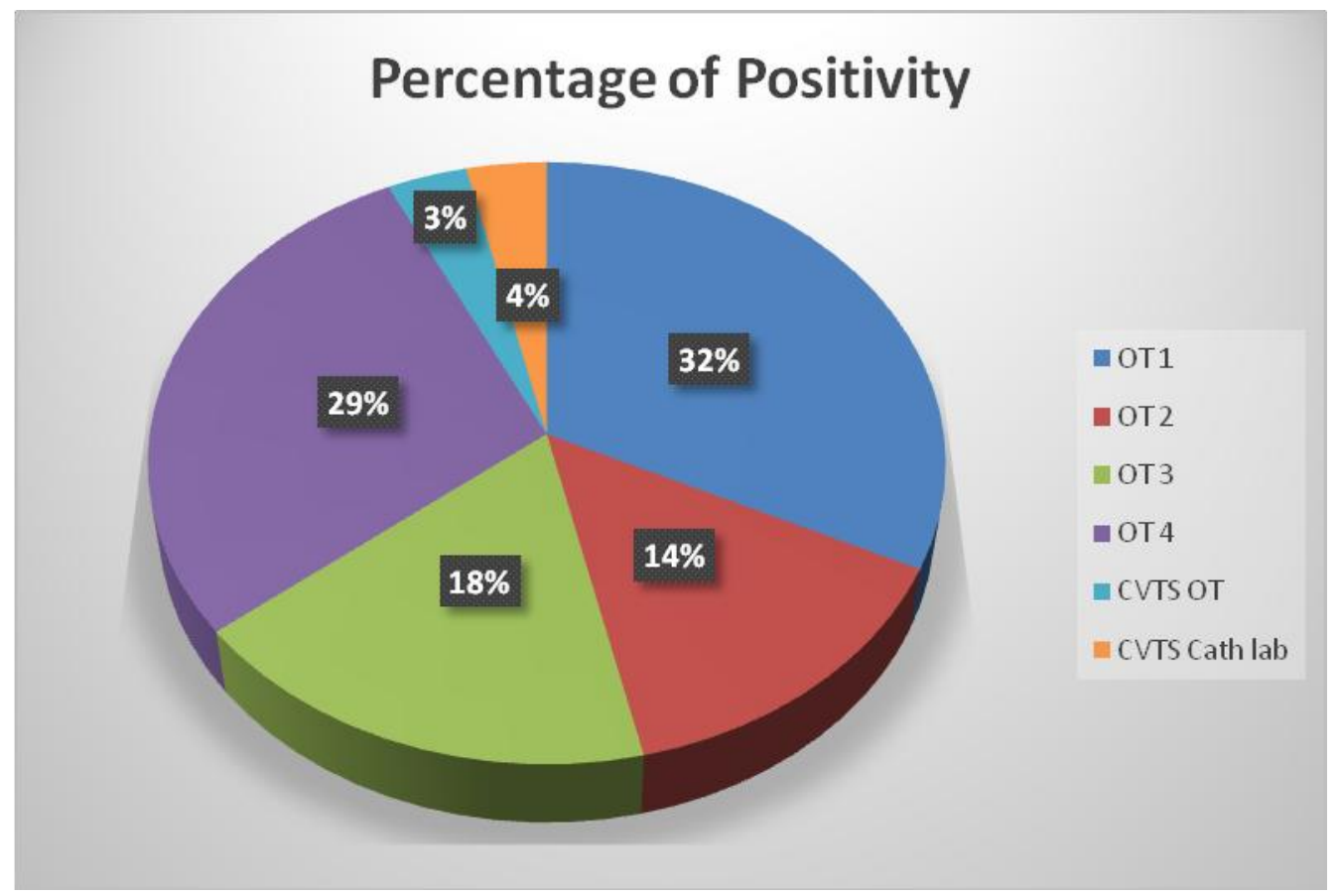


Fig.3 Shows Percentage Distribution of Different Organisms Isolated from Unsatisfactory Samples from all ots. 57\% samples had colonies of staphylococcus aureus, $7 \%$ samples showed colonies of pseudomonas species, $7 \%$ samples had fungal colonies of Aspergillus niger and 29\% samples had significant colony count of other gram negative bacteria (other than pseudomonas species).
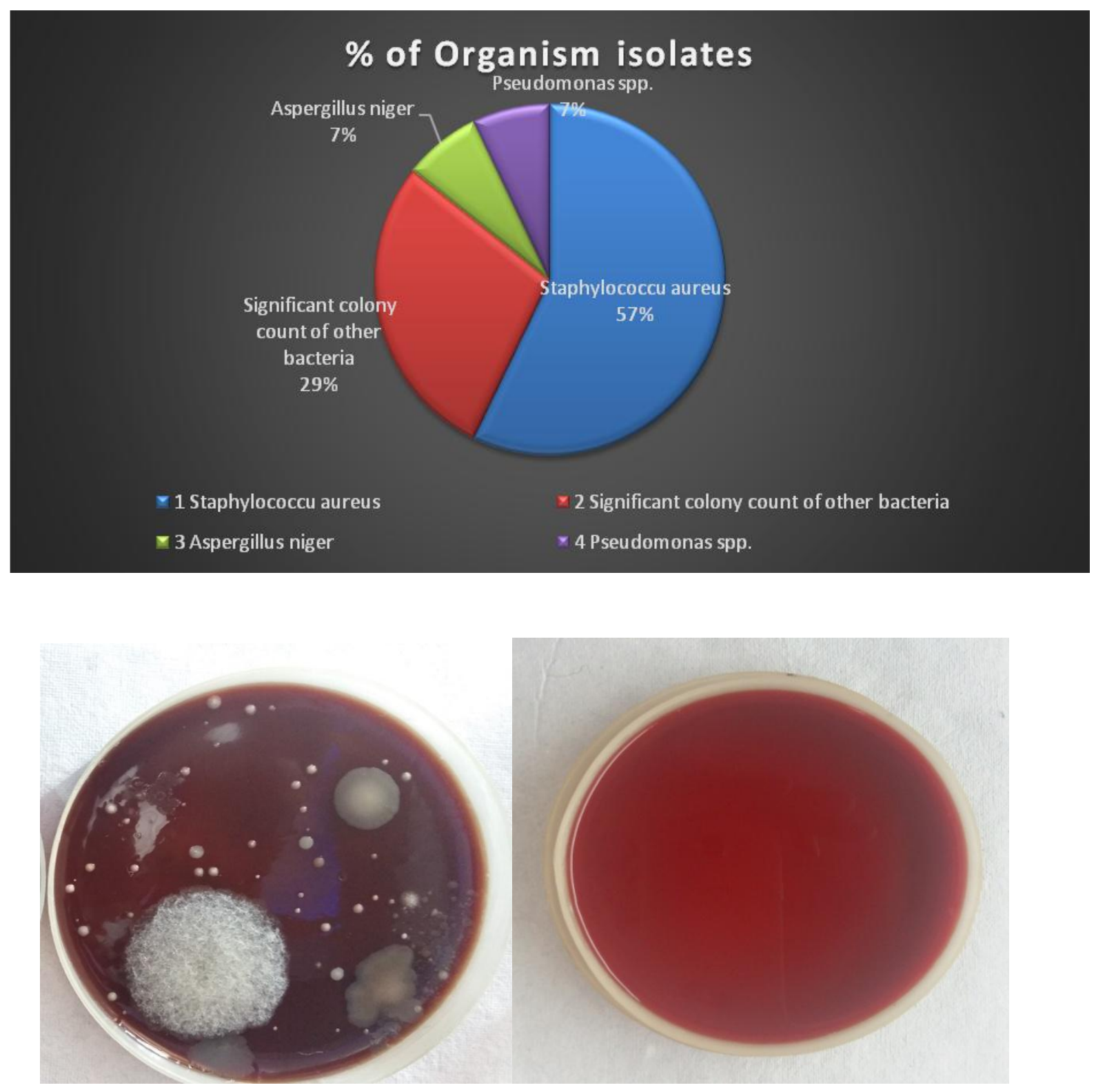

Agar plate showing fungal colony with other bacterial colonies, significant count.

\section{Control Blood agar plate showing No growth.}




\section{Agar plate showing less than 15 colonies}

\section{Agar plate showing CFU $>15$, significant colony count}
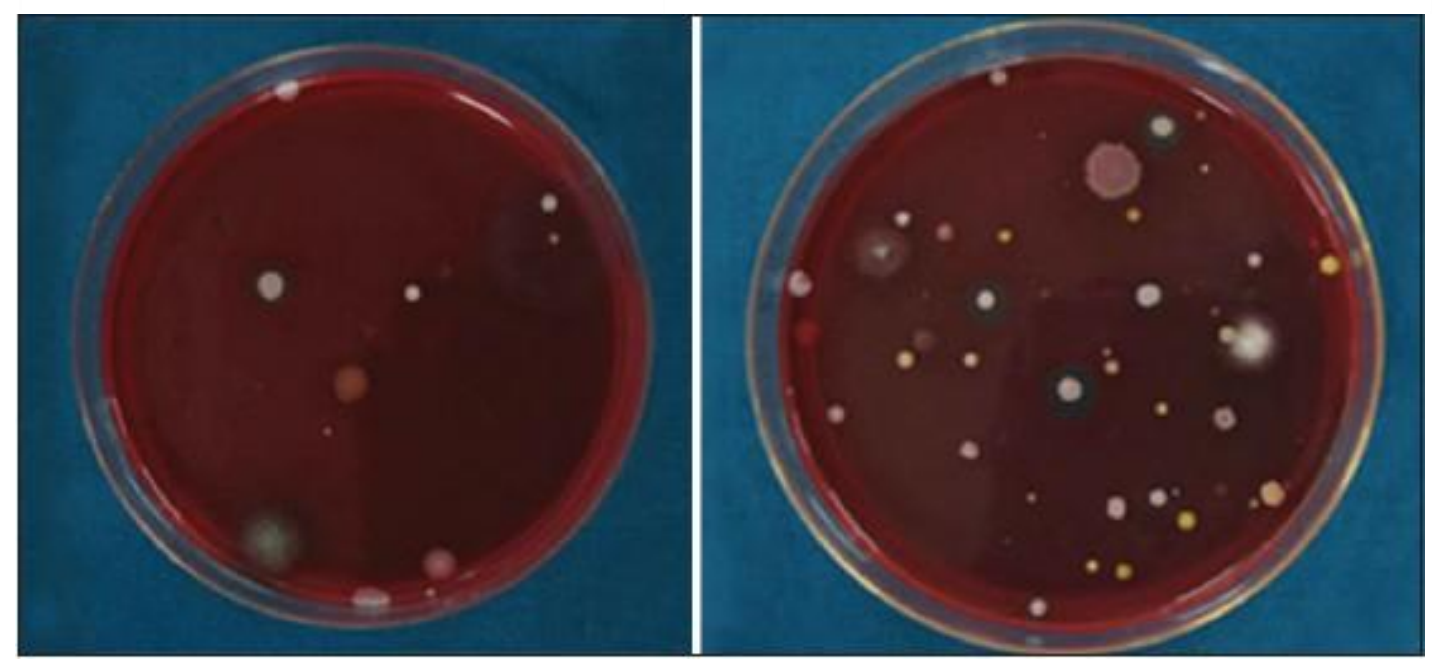

Many studies have suggested that higher concentrations of these cocci can be attributed to the lower susceptibility of these organisms to environmental stresses, due to the presence of pigments and higher peptidoglycan contents in their cell walls, which provides protection from drying and heat stress (Raymond et al., 2001) Other reasons include improper ventilation whose effect is worsened when the number of people present are beyond the room's reasonable capacity, since the main source of Staphylococci are people who shed these cocci from skin, clothing, and hair (Borriello et al., 2005).

Gram negative bacteria get generated and dispersed in air in the form of aerosols from contaminated fluids from humidifiers, nebulizers, and wet cleaning equipment (Ayliffe et al., 1982). Earlier studies, however, have shown that Pseudomonas species are ubiquitous and found to be present in air, soil and other inanimate objects (Rughooputh et al., 2001). They are difficult to eradicate from hospital wards as it is resistant to and may multiply in many of disinfectant and antiseptics commonly used in hospitals (Zimakoff et al., 1983). Fungus like Aspergillus species can be transmitted from patients or the environment. Aspergillus species may be dangerous for patients of risk group. The tiny spores readily invade upper and lower airways and may produce lung Aspergillus in risk group patients (Anaissie et al., 2003).

In conclusion, harbouring of potential pathogens in OTs of hospital can pose a great risk to patients. Monitoring the bio load of air helps in assessing the capability of air filters used in the OT's and also helps in assessing quality and making timely changes in measures that need to be adopted. This data can be used to set regional standards for levels of acceptable microbial population and can also be used to suggest suitable guidelines in order to decrease the microbial rates in indoor air.

\section{Reference}

Anaissie, E.J., et al. 2003. Pathogenic molds (including Aspergillus species.) in 
hospital water distribution system: A 3 year prospective study and clinical implication for patients with hematologic malignancy Blood. 101: 2542-2546.

Ayliffe, G.A.J., Lowbury, E.J.L. 1982. Airborne infection in hospital. J. Hosp. Infect., 3: 217-240.

Bhalla, A., Aron, D.C., Donskey, C.J. 2007. Staphylococcus aureus intestinal colonization is associated with increased frequency of $\mathrm{S}$. aureus on skin of hospitalized patients. BMC Infect. Dis., 7(1): 1.

Borriello, P.S., Murray, P.R., Funke, G. 2005. In Topley and Wilson's Microbiology and Microbial Infections: Bacteriology-I, $10^{\text {th }}$ edn, Washington D C, American Society for Microbiology Press, 2005, pp. 185-194.

Javed, I., Hafeez, R., Zubair, M., Anwar, M.S., Husain, S. 2008. Microbiological surveillance of operation theatres and ICUs of a tertiary hospital, Lahore Biomedica, vol 24: 99-102.

Rajni Sabharwal, E., Rajni Sharma. 2015. Estimation of microbial air contamination by settle plate method: are we within acceptable limit. Sch. Acad. J. Biosci., 3(8): 703-707, ISSN
2347-9515.

Raymond, D.P., Pelletier, S.J., Crabtree, T.D., Schulman, A.M., Pruett, T.L. 2001. Surgical infection and the aging population. Am. Surg., 67(9): 827-832.

Rughooputh, S. 2001. The role of Pseudomonas aeruginosa in nosocomial infections, Biomed. Scientist.

Sehulster, I., Chinn, R.Y. 2003. Guidelines for environment infection control in health care facilities.

Recommendations of CDC and the healthcare infection control Practices. Adivisory committee MMWR Recomm Rep., 52: 42.

Srikant, P., et al. 2008. Bio aerosols in indoor environment: composition, health effect and analysis. Indian J. Medical. Microbiol., 26(4): 302-12.

Whyte, W., Hambraues, A., Laurell, G., Hoborn, J. 1992. The relative importance of the routes and sources of wound contamination during general surgery. II Airborne. J. Hosp. Infect., 22: 41-54.

Zimakoff, J., N. Holby, K. Rosendal, Gulbert, J.P. 1983. Epidemiology of Pseudomonas aeruginosa Infection and role of contamination of the environment in a cystic fibrosis, Clin. J. Hosp. Infect., 4: 31-46.

\section{How to cite this article:}

Kasdekar, M.M., M.M. Duthade, A.S. Damle, M.N. Khapurkuntikar, J.A. Iravane, J.B. Bhakre and Gaikwad, A.A. 2016. Air Quality Monitoring of Operation Theaters in Government Medical College and Hospital, Aurangabad. Int.J.Curr.Microbiol.App.Sci. 5(6): 42-49. doi: http://dx.doi.org/10.20546/ijcmas.2016.506.005 